\title{
Movement for the "Emancipation of the Niger Delta" (MEND) Constitutes a Threat to the U.S. National Security
}

\author{
Mustapha Kulungu \\ ILM Foundation Institute of Los Angeles, Los Angeles, USA \\ Email: drmkulungu@yahoo.com
}

How to cite this paper: Kulungu, $M$. (2021) Movement for the "Emancipation of the Niger Delta" (MEND) Constitutes a Threat to the U.S. National Security. Open Access Library Journal, 8: e7465.

https://doi.org/10.4236/oalib.1107465

Received: April 28, 2021

Accepted: June 13, 2021

Published: June 15, 2021

Copyright $\odot 2021$ by author(s) and Open Access Library Inc.

This work is licensed under the Creative Commons Attribution International License (CC BY 4.0).

http://creativecommons.org/licenses/by/4.0/

\section{(c) (i) Open Access}

\begin{abstract}
Since the discovery and commencement of oil production in 1956 in the Niger Delta, the region has worsened in terms of security, poverty, and environmental pollution. The "Movement for the Emancipation of the Niger Delta (MEND)" is among the insurgent groups that continue to cause havoc in the region. The Delta Niger area is infested with corruption, economic inequalities, lack of opportunities, political repression, nepotism, and so on. All these problems must be addressed equitably and promptly. If these issues are not resolved, they may cause security instability as well as insurgency. The insurgency in Niger Delta is a menace to Nigeria's national and the stability of W. Africa and the U.S. interest. The paper brings out the history of the group, threat analysis, and recommendations on actions to be taken to mitigate the prospect of an attack.
\end{abstract}

\section{Subject Areas}

Politics

\section{Keywords}

Movement, Emancipation, Niger Delta, Threat, Security, Kidnapping

\section{Introduction}

The Niger Delta is an oil-rich region that is currently associated with insurgency. The "Movement for the Emancipation of the Niger Delta" (MEND) has been attacking oil installations, oil corporations, and security forces. The region faces various security crises, including kidnapping, terrorism, militancy, drug trafficking, and sea robbery [1]. The MEND Insurgency is an example of the "re- 
source curse phenomenon that seeks to establish strong connections between natural resource abundance, the paradox of plenty and violent conflict in third world countries." [2] The group has not only overwhelmed the security apparatus of Nigeria but also threatened America's national security. For instance, various abductions of foreign nationals and terrorist attacks have provoked international condemnation. Such acts threaten Nigeria's stability and the stability of West Africa and the U.S. interest. Nigeria's dependability is critical in boosting the U.S. prosperity and security, considering its regional influence and the U.S. economic interests.

\section{Background and History of the Group}

Since 2005, the resistance against multinational and state oil corporations that operate in Niger Delta has taken a sophisticated and more violent turn due to the emergence of MEND [3]. The region has witnessed the rise of abductions of expatriates and local workers and attacks on oil facilities. The activities of MEND and other groups which operate in this region have contributed to the shut-down of nearly a quarter of oil production [4]. The crisis culminated in unaddressed grievances like political repression, land dispossession, marginalization, and pollution. The massive population of Nigeria, its natural resources, and growing economy provide ample opportunity for expanded cooperation. Nigeria has been a significant oil supplier to the U.S., supplying 53\% of American oil imports from Africa, which constitutes nearly 8 percent of all U.S. oil imports altogether worldwide [5]. Consequently, Nigeria is among the countries receiving the highest U.S. aid, totaling about $\$ 600$ million yearly since 2011 . Thus, it means that its stability and also regional security, are in the U.S. interest. Recent studies have gone beyond war economies towards giving explanations for how a dangerous mix of corruption, state failures, poverty, and conflict has generated a global security threat [6].

In 1990, the minority communities in the region which had been living in poverty decided to take actions against the exploitations of their resources [7]. It left a legacy of polluted water and soil, rusted pipelines crisscrossing farmlands, frequent gas flares, and oil spillages. The people peacefully demonstrated against Shell, and the company called for security in the event of violence. Instead of protecting everyone, the police instead destroyed 495 homes and massacred 80 people [8]. As much as inquiries blamed the police, the resident held Shell responsible [9]. Protesters have since then been met with similar or worse brutality. Those opposed to oil companies and the Nigerian government, have increasingly been radicalized. There were calls to clean up the environmental damage and also political autonomy by the "Movement for the Survival of the Ogoni People" (MOSOP) [10]. The movement demanded immediate compensation for ecological damage from the company. However, MOSOP became under pressure from the government to halt the campaign. Its leaders were harassed and detained. During elections in May 1994, four chiefs in the region, including 
MOSOP's former vice president, were murdered. Instead of giving justice to the local community, the police instead claimed the Saro-Wiwa and the other ten activists in the region incited the killers. "On November 1995, Saro-Wiwa and eight other activists were executed". Nigeria received international condemnations. The country was even "suspended from the Commonwealth and then given two years to return democracy or face expulsion."

The situation in the region was made worse by the availability of small arms [11]. The region's security forces often engaged in the confiscation of property, torture, and killings. It led to increasing insecurity, which included attacks on oil installations. In April 2006, then-President Obasanjo proposed a plan for the region. However, he involved corrupt local officers and excluded many civil society groups which enjoyed massive credibility within the area. Further attacks made President Obasanjo order a crackdown in August 2006. Soon, both international and local oil workers' kidnappings rose steadily, with the militants even resorting to abductions of children. The militants' grip on the region was illustrated in 2007 when the government troops tried arresting a prominent militia leader. The country experienced running battles when the fighting rocked the country's central oil city. When President Yar'Adua appointed Jonathan, who comes from the region, as his deputy, the government released the "detained leader of Niger Delta People's Volunteer Force, Mujahid Dokubo-Asari, and the vice-president embarked upon a series of meetings with leaders of the different communities in the Delta." [8] The leading militant group (MEND) then called a ceasefire which lasted for only a few months. Towards the end of 2007, the attacks and kidnappings resumed.

On June 4, 2008, the long-running disputes between Shell and local communities ended when the government decided to replace the company as the operator of "oil concessions" in Ogoni regions. Conflicts erupted again "when the government announced that the concession would be taken over by the Nigerian Petroleum Development Company (NPDC), the upstream subsidiary of the state-owned Nigerian National Petroleum Corporation (NNPC)." [12] The local communities saw this as another denial of the locals' rights. As a result, guerrilla activities by MEND stepped up in the region from September 2008. The group released statements saying it has launched an oil war against oil production facilities, pipelines, and the soldiers protecting such facilities. The Nigerian government and MEND both claim that they have inflicted enormous casualties on one another.

\section{Research Methodology}

Various sources containing historical details of the insurgency are vital in understanding the situation's evolving nature and mitigating the risks. The data regarding the uprising in the region were collected using historical research methods [13]. The use of archival research and document analysis has proven to be crucial in security studies. Analyzing historical narratives through deductive and 
inductive reasoning helps create inferences about the past. The research relies on various publications, trade journals, newspapers, magazines, and relevant reports to understand the historical events.

Understanding the threat, assessing, and mitigating it has been researched for many centuries, and lately, it has intensified in the last six decades. The issue of mitigating threat has been the focal point of the U.S. Department of Homeland Security's Risk Dictionary describes risk as "potential for an adverse outcome assessed as a function of threats, vulnerabilities, and consequences associated with an incident, event, or occurrence." (p. 27) [14] Each government, be it small or big, has the full responsibility to provide security protection to its citizens and business from internal and exterior danger. And doing so will continue to provide security stability and economic prosperity for the effective functioning of a government.

The central focus of MEND's attacks has been to target wherever they can maximize human fatalities and economic loss to destabilize the running orders of the targeted government. The group is likely to hit various infrastructures, such as buildings, transportation, and related assets in Nigeria. These pipelines carry crude oil from oil rigs to the refineries, oil tanks, ships, and gas stations. Thus, there is a growing outcry and demand for physical security threat assessments for the Nigerian infrastructures to mitigate economic instability in the region and slow the U.S. oil import from Nigeria. Threat assessment examines governments' capability to quickly and precisely respond in real-time to protect their people, businesses, assets and lessen the magnitude of danger in losing human lives and economy [15].

The research employs threat analysis methodologies such as security threat analysis or risk assessment to collect data on the security threat. Overall, a security threat or risk assessment is designed to examine a transportation system's exposures to security threats and identify weaknesses and possible costs. The area's exposed limit may be calculated for a given radius. It helps in pinpointing the most vulnerable regions. It is a principal instrument for determining the likelihood of an attack is a risk assessment. According to Boyd and Sullivan, they describe a risk assessment as "a comprehensive study of a transit agency to identify components that are most vulnerable to criminal activity, including acts of terrorism, and to assess the impact of such activity on passengers, employees, and the agency." This assessment instrument is also employed to delineate a method through which operational entities perceive and detect possible, immediate, or looming danger [16].

The security threat analysis also involves critically examining what is in place and needed countermeasures to eliminate if possible or at least minimize these threats. We assess the security threat and vulnerability by understanding what can go wrong, how likely the threat will occur, and the consequences if it happens? Subsequently, the assessment outcome helps the intelligence and security community make crucial decisions to apportion valuable and needed resources 
to protect human lives and infrastructure [17]. In addition, understanding the threat and vulnerability will assist the government in prioritizing the danger.

It is wise to learn from U.S. Federal Emergency Management Administration (FEMA) approach when identifying infrastructural threat in the Niger Delta. According to FEMA, this approach is so critical before establishing a plan of action and, according to FEMA, identifying a potential danger or visualizing a scenario of a disaster they may encounter. This is an essential step for the reason that identification is localized and executed as the local people see it fits. In the Niger Delta, militants constantly threaten to attack the most critical oil installations and military bases in the southern region. As stipulates by FEMA, a pearl of conventional wisdom is that various geographical locations of Nigeria face more security challenges and threats than others. Consequently, emergency contingency must properly visualize and anticipate the most likely danger unfolding to mitigate the impact and loss of lives and assets [18].

It makes perfect sense to conduct a threat analysis approach that helps us understand how our enemies (MEND) capitalizes on the most vulnerable locations on the Gulf of Guinea for piracy and land oil installations pipelines for political and economic gain. So, recognizing a weakness in the system identifies the possible threat. Enhancing the security of the infrastructure may entail reinforcing the doors, windows in the most vulnerable buildings to prevent bullets, woods, or any object from flying into installations if an attack or an explosion happens. Doing so helps the government enhance the security that will minimize vulnerabilities exposure to threats before a mitigation plan of action.

Piracy endangers the flow of goods, including crude oil, which is the commodity the U.S. imports from Nigeria. MEND's piracy in the Gulf of Guinea accounted for over 95 percent of ship crew personnel kidnapped. Just in 2020 alone, there were 35 documented incidents of piracy in the coastal region of $\mathrm{Ni}$ geria [19]. The group has been driven by the profit from kidnappings due to declining oil prices. MEND is well equipped with speedboats, and weapons force many maritime and oil companies to spend a lot of money on buffing up the protection of their personnel and oil installations [18].

The government of Nigeria, the maritime and oil companies, must be better prepared to protect their human and physical assets against possible and looming terrorist attacks. Threat analysis offers a concise and upfront account of the threat assessment method. Protective intelligence \& threat assessment inquiries are tools for stakeholders from both government and business sides with protective mandates. Threat analysis alone is inadequate to support the most significant decisions that must be decided. Nonetheless, in combination with understanding vulnerability and exigency assessments, people in charge will have adequate information to make sound decisions built on this threat analysis method.

\subsection{Root Causes of Terrorism}

When studying the root causes of terrorism, we are confronted with various de- 
grees of terrorism, requiring different interpretation levels. This is beyond this study's scope; however, we recognize that terrorism can occur in multiple places for other reasons. This research fully acknowledges that terrorism has no boundary. It is gender blind; thus, it may deprive and uneducated people, affluent and educated segment of the society.

Terrorism does not happen in a vacuum without underlying contributing factors. These contributing factors are known as the root causes, although some may disagree with the actual reasons. There is some causal connection between fundamental economic, political, social, and demographic changes. These conditions may breed terrorism activities. Ignoring the relationship with these underlying grievances may exacerbate the critical constraints on the ground where the circumstances exist. Research has found that poverty combined with weak states under oppressing regimes has higher degrees of terrorism than in societies with flourishing and stable countries. In 2004, Lia and Skjølberg conducted a study on the causes of terrorism and indicated that weak and failed states contribute to international terrorism. Failed states and corrupted governments are much more exposed and prone to civil wars than secure and stable nations [20].

Prevalent deprivation and inequality serve as the underpinning contributing factors that drive people to collectively participate in civil violence and join organized crime groups for survival when their grievances have not been adhered to by their government. In 1998, David Keen conducted a study on the economic functions of violence in civil wars. He suggested that failed states fail to create a sustainable economy and prosperity perpetuates the continuation of civil war and violence [21].

Also, easy access to weapons and armed conflicts has tremendously contributed to transnational terrorism. In 2004, Thomas Sanderson researched international terrorism and organized crime. He found that transnational organized crime has become a lucrative source of income for terrorist and militant groups globally [22]. Basically, by definition, we can say that MEND is an organized group that has engaged in organized criminal and economic terrorism. In 2004, Quan Li and Drew Schaub conducted a study about economic globalization and transnational terrorism [23], and previously in 1983 study conducted by Brian Jenkins of RAND Corporation regarding the future trends of conflict in international terrorism suggested a strong correlation between economic deprivation and inequality, and political circumstances and terrorism. Additionally, their studies corroborated similar findings previously found in civil war studies [24].

\subsection{Key Issues and Environmental Factors}

The keys issues that have led to insecurity and insurgency in the region can be summarized as corruption, political repression, land dispossession, marginalization, and pollution. Since the oil discovery in Nigeria, politics has been mainly bout the scramble for petrodollars [25]. Based on the World Bank report, "nearly $80 \%$ of Nigeria's oil and natural gas revenues accrue to $1 \%$ of the country's population [26]. The other $99 \%$ of the population receive the remaining $20 \%$ of the 
oil and gas revenues, leaving Nigeria with the lowest per capita oil export earning put at \$212 per person in 2004 [27]." To make matters worse, most of the wealth which accrue to the $1 \%$ end up outside the country. The $1 \%$ consists of the country's elites who keep most of their wealth abroad. Thus, most Nigerians are not only excluded from the oil profits but also most wealth isn't invested within the country [28]. It contributes to the scenario where most Nigerians live below the poverty line. Many agree that oil has been "more of a curse than a blessing" in Nigeria [29]. The oil wealth tends to go to public officials, robbing the country's development and leave the people destitute. The Niger Delta area is the worst affected region.

Protests and concerns have often been raised about the environmental effects of oil extraction on the region. In 2015 the "U.N. Special Rapporteur for minority issues" visited Nigeria and expressed concerns on the continuing impacts of pollution from spillages, especially in Ogoniland [30]. The law firm representing the affected communities has also expressed concerns about the pollution, urging Shell Company to walk away. As mentioned earlier, oil mining has left a legacy of polluted water and soil, rusted pipelines crisscrossing farmlands, continual gas flares, and oil spillages.

\section{Threat Assessment (Intent, Capability, U.S. \& Partner Vulnerability, Likelihood)}

They intend to localize "the control of the country's oil" and secure reparations for pollution from the federal government. Based on an interview with one of its leaders, the group's efforts are directed towards crippling the oil production in the region [31]. It seeks to stop the oppression and exploitation of locals and devastate the environment, contributed by public-private partnerships between oil corporations and the government.

MEND is a movement with no clear leadership structure. It has an amorphous and diverse leadership style to make it elusive. The initial plan of Nigeria's government to "disrupt the criminal godfather system in the Niger Delta" has failed to restore peace [32]. The plan involved removing corrupt personnel, allocating funds for amnesty payments, and contracting security to demobilize ex-militants. Towards the 2015 national elections, it was apparent that the militant groups in Niger Delta were fighting each other upon being supplied with weapons. As a result, new alliances and groups were emerging as former militant networks were weakening due to the absence of patronage and funds by the previous government. These developments started taking shape in mid-2015 when privileges were removed gradually by the government. By 2016, new groups like Niger Delta People Democratic Front (NDPDF) and Concerned Militant Leaders (CML) became more public, seeking public attention and influence. The threats of violence resumption abounded whenever the government raised the issue of termination or reduction of the amnesty program [33].

The groups' decision to have no single and hierarchical command structure 
has made the movement elusive but effective for guerilla warfare in the entire region. The group has proven that it's capable of sabotaging oil production. Its invisible nature has made it almost impossible for the military, oil corporations, and the government to target and effectively thwart its activities. Various groups who had hierarchical leadership were quickly targeted and eliminated. The group has proven that it's capable of blocking the global oil trade using its local force. The international attention has shifted to the situation, particularly on the plights of the people. The group has raised "the energy security stakes of the world's established and emerging powers in the region. MEND has tapped fully into acts likely to draw global attention to the Niger Delta: the taking of western nationals as hostages and the shut-ins resulting from oil facility destruction that contribute to the higher price of crude oil." [8] The acts have been claimed to be $s$ strategy to get the attention of the global media and intervention agencies to the plight of people living in the region [34].

The stability and prosperity of Nigeria and its regional security are in the U.S. interest. The abductions of western nationals and destructions of oil facilities, leading to higher crude oil prices, make the U.S. and other partners vulnerable to the insurgency. As mentioned earlier, Nigeria has been a significant oil supplier to the U.S., supplying 53\% of American oil imports from Africa. Thus, the activities of the militants pose threats to this trade. Nigeria is also among the countries receiving the highest U.S. aid, totaling about $\$ 600$ million yearly since 2011 . It means that the U.S. is also vulnerable to the effects of insurgency in the region; hence, Nigeria's stability and prosperity and its regional security are in the U.S. interest.

\section{The Failed-State}

Security is perceived as one of the most essential and critical tools for the growth and development of a nation. Noticeably, a nation's prowess is measured by the level of security it enjoys, among other issues. With a secure operating environment, investors will often feel attracted to start up their ventures as they consider venturing into areas that will guarantee their investments. Therefore, in ensuring stability and an effective operation of a country, states need to create an enabling business environment that will promote economic growth and development and protect the lives of its citizens.

Political and economic systems are critical determiners to the stability and prowess of a nation. Markedly, a country that enjoys political stability is said to have the potential of attracting investors resulting in the development and growth of the economy. Given the current climate in the Niger Delta region, the Nigerian government is a failed state. Thus, it cannot attract new foreign investors due to its lack of security stability. For instance, there will be peaceful coexistence between communities, a functional government in place to protect the rights of its citizens and enhance the rule of law. A strong and stable government provides security to its people alongside others who reside within its jurisdiction. 
On the other hand, political instability may cause the complete opposite of what a United Nation entails. A state that lacks stability in its political and economic system suffers several setbacks in its operations. For example, political instability may lead to a state of lawlessness and anarchy, where people rule themselves, and there is no one to observe the law. The situation may result in insecurity and tension and the possibility of conflict emerging due to various groups forming and creating authority as there is no government in place. Hence, in understanding the significance of political and economic stability, this research recognizes, briefly discusses, and analyzes the context of a failed state and the importance of addressing the issues that may lead to the failures of states.

Understandably, a failed state is perceived as that state that cannot perform some of the two fundamental functions, a sovereign nation-state in the modern global system. The government in control is weak and cannot command authority over its territorial borders and its citizens, besides being unable to safeguard its national boundaries. Remarkably, the governing ability of failed states is usually attenuated so that they are unable to fulfill both the administration and organizational duties needed to control and govern people and resources. In a failed state, citizens have no trust in their system, making the state illegitimate before the international community [35]. In addition, there is the presence of feeble and weak institutions with the executive barely functioning, whereas the judiciary, the legislature, alongside the armed forces losing their capacity and professional independence. They suffer from collapsing infrastructures, hesitating utility supplies, educational and health facilities, alongside declining fundamental human development indicators, like literacy and infant mortality rates.

The dynamics resulting in a compounding failure of a state are several and varied, for example, civil war, bureaucratic behavior, ethnic genocide, and predatory government. Some of the factors that may lead to state failure include the collapse of government institutions and the breakdown of societal norms. The given state cannot formulate policies to effectively promote infrastructure alongside delivering services to its people or safeguard civil liberties and fundamental rights of humans. Therefore, state failure tends to manifest itself if a government cannot deliver physical security, ensure a stable political system, and create a productive and enabling economic environment for its people. Rotberg connotes that failing and failed states present grave danger not only to the local populace but also has an impact on international stability and to the well-being of their people [36].

Failed states are often perceived to create safe havens for extremist groups, grounds for the trade of illegal drugs and firearms, and the breeding ground for various diseases. According to Rice, a failed state experiencing anarchy can end up spilling instability across its borders. This instability creates a conflict dynamic that may affect neighboring countries, like the case with Afghanistan, the Sub-Saharan region of African, central such as Congo Brazzaville, the Democratic Republic of Congo (DRC), Gabon, Cameroon, to name just a few [37]. Since the overthrown state cannot protect its borders. Failed states create an en- 
vironment that spurs broader regional conflicts with substantial economic and security costs to the neighboring nations. For instance, the impacts of failed states pose severe challenges to America's interests regarding refugees' flow, lost trade, trafficking in illegal goods, and investment opportunities. Moreover, there will be a need for peacekeeping and humanitarian assistance and adopting strategies that have visionary policies and ways of countering these threats.

Generally, there is no agreed worldwide list of failed states, as all states are deemed to have failed in some respects. Furthermore, a state also can move in and out of fragility. For example, Zimbabwe had enjoyed moments of steady economic growth and development before the early 1990s. The Military operations in the Democratic Republic of Congo have left the nation in political instability, contributing to the decline of the country's economy by $30 \%$ over the past few years, making it unable to service its external debt, with continuous quest humanitarian assistance [38]. The World Bank's Country Policy and Institutional Assessments (CPIA) has divided the low-income states into five different performance classes, giving a list of 46 fragile states, with a population of about 870 million.

The real threats posed by fragile and failed states have resulted in calls for early global intervention to address the effects brought about by these states before the situation worsens. The demand for external interventions to stabilize the states that are about to collapse is quite large compared to the limited available resources [39]. Besides, there is also a lack of knowledge on the kinds of approaches that can enable these states to recover alongside the various instruments suitable for undertaking the initiative. So far, the international community has dealt with fragile states in an ad hoc, piecemeal fashion, where a situation is looked into only after it has become critical. Thus, a sustainable approach to dealing with fragile states remains elusive. Energy should be focused on reconstructing fragile states. Some of the strategies that can be embraced to avert and save nations from finding themselves in a failed state are by advancing intelligence collection, especially around areas prone to state collapse, by focusing specifically on transnational security threats like smuggling terrorism, and crime among others. There is also the need to take risks for peace by taking initiatives to prevent conflicts and efforts to broker peace [40] This has been seen in the energetic efforts by the U.S. to defuse tensions between Pakistan and India. Additionally, nations should also help the fragile states recover by providing aid, trade, and debt relief.

\section{Non-State Soldiers of Africa}

The existence of non-state soldiers is no longer a threat to one nation. Still, it is becoming a global issue considering the security threats these groups pose to international security. The non-state soldiers possess unique capabilities, including tactics; thus, the groups are becoming a threat to many nations considering their ability to cause disaster in many parts of the world [41]. The soldiers possess unique characteristics that make them accomplish their heinous acts. Africa has 
not been left out, considering several non-state soldiers in the continent. Such soldiers threaten the nations they reside in and other international states like the United States.

The Movement for the Emancipation of the Niger Delta (MEND) is an armed group that has built its territory in Niger Delta, and it's the largest militia organization in Nigeria. Economic equalities in Nigeria might be associated with the increased number of militia groups in the country [42]. However, the land being rich in oil infrastructure, MEND focused on attacking these infrastructures. Still, they aim to exploit and oppress civilians in the Niger Delta and devastate the natural environment due to public-private partnerships between corporations and the Nigerian Federal government. The group members include Ijaw, whose main objective is to disrupt international oil firms and the government, arguing that they facilitate economic disparities and inequalities, environmental degradation, and fraud in Niger Delta.

The MEND employs different strategies and methods such as staging armed assaults on oil infrastructure sides, kidnapping and taking ransom of oil employees, murder of Nigerian military and armies, destroying oil pipelines and draining off oil the pipe and selling off in the black market. The group uses swarm-based maneuvers, including the use of speed boats in swamps that outsmart the government's defensive systems. Group's goals include localizing oil control in Nigeria and secure reparations from the government due to population increase due to the oil industry [43]. Several attacks that have been experienced in Nigeria, especially Niger-Delta, such as guerrilla warfare, sabotage, theft, kidnapping, and property destruction, are linked to MEND; thus, the group is a threat regionally in Niger-Delta and the whole of Nigeria.

Taking the above discussed armed groups in different countries in Africa with unique capabilities, strategies and characteristics, indicate how dangerous these groups are regionally and internationally. It also notes more that needs to be undertaken by security agencies and international organizations such as United Nations to control such non-state soldiers in different states because they pose a threat. Failure to formulate global strategies and focus on such groups may expand and develop to more lethal terrorist groups.

The real threats posed by fragile and failed states have resulted in calls for early global intervention to address the effects brought about by these states before the situation worsens. The demand for external interventions to stabilize the states that are about to collapse is quite large compared to the limited available resources [39]. Besides, there is also a lack of knowledge on the kinds of approaches that can enable these states to recover alongside the various instruments suitable for undertaking the initiative. So far, the international community has dealt with fragile states in an ad hoc, piecemeal fashion, where a situation is looked into only after it has become critical.

\subsection{Using Soft Power to Counter-Terrorism}

Many terrorist organizations apply violence as a means of realizing their objec- 
tives. In this regard, hard power has been used in the past to counter extremism. MEND subscribes to ideologies and beliefs that appeal to a broad audience in the southern states [44]. Applying counterterrorism initiatives that embrace soft power has been hailed as fruitful instead of the use of force or military power. Although soft power has received to extent minimal attention in combatting terrorism, there is a need to devise tactics that do not include hard power [45]. In the case of Nigeria's MEND, the government has not explored the use of hard and soft power together. Soft power entails using all-inclusive methods that primarily focus on social, economic, and political causes.

Using Soft and Smart Power by appealing to civil society and community actors is an indispensable strategy that governments should employ in countering militant groups. Soft power helps bring to an end the new terrorist recruits' flow [46]. Old strategies to counterterrorism have been unsuccessful for the reason that they target individuals with already transformed identities into terrorists. An all-inclusive tactic to dealing with the circumstances causing social polarization and in-group/out-group violence is essential if governments desire to win the asymmetrical conflict. Soft power and Smart Power describe methods to influencing terrorist behavior without threats, sanctions, and coercion [47]. Soft power influences terrorist behavior through changing preferences [48]. It relies on attracting cultural, political values, and foreign policy forces.

\subsection{Using Non-Kinetic and Non-Lethal}

When dealing with militant groups, all approaches and options must be used to achieve the desired outcome. One of these approaches is using non-kinetic or non-lethal tools. The purpose of using non-lethal means is to hinder the capability of the adversary. When we use information technology to target their critical information systems such as communication and computer, it gives us an advantage of disabling their ability. For instance, we can cause to deflate tires on a vehicle, and in so doing, it will disable the automobile from being used in an attack [49].

The same approach can be used when we attack their information technology by overloading it with that to the point that the computers crash and wipe out the entire system by installing malicious commands that will damage the overall functionality of those computers. By overtaking their information system, we can prevent them from accessing their system, and they will be hindered from responding or coordinating any attack electronically. The information security experts and hackers call it a denial of service [50]. In a nutshell, the strategy of employing cyber-attacks give the advantage to attain our goal without firing a conventional weapon that may kill a person.

\section{Recommendations/Options}

Nigeria's responses to the insurgency in the region have focused mainly on providing security for oil production facilities. To fully address the region's issue, deploying the armed forces may not offer a long-term solution. This ar- 
ticle recommends various non-kinetic activities that might address factors such as motivation and access to weaponry, among others, to help restore peace. First, the military needs to collect intelligence and infiltrate the networks of the militia to be able to understand how they operate, how they communicate, and obtain funds that they use to carry out their activities [51]. By identifying their center of gravity, the military will know what will hurt them the most. Intensive intelligence gathering will also help the military to understand how they access their weaponry [52]. Once the military has sufficient and reliable information, it should commence a crackdown on the militia, including cutting their funding, crippling their access to weaponry, infiltrating their communication network, arresting and prosecuting members of the group [53].

Also, this research recommends the strengthening of host-government forces. It would involve providing training and military equipment which will help them fight the insurgents. Training the troops of the host government will provide them with the necessary skills and tactics to help them curb terrorist [54]. In return, the U.S. will find a helpful ally. Therefore, the strategy can be summarized as monitoring, suppressing, attacking, and eventually eradicating terrorists.

\section{Risk of the Options (Ups and Down)}

As much as the above options may be effective, there are various risks associated with these strategies. For instance, infiltrating the network on terrorists is very risky. The person going undercover is at extremely high risk because he may blow his cover. The terrorists may also, along with the person, covert and lead the military into a trap. The damage that such miscalculations will do is so enormous, leading to massive loss of lives and shutting down such military operations.

The other risk may involve having to work with an unsupportive regime that considers the U.S. as a country with an ulterior motive [55]. The U.S. has faced criticisms for its operations in Libya and Afghanistan. For instance, in Libya, the country has been in crisis since the insurgency began in early 2011, resulting in the killing of Muammar Gaddafi on October 20, 2011. In other words, the lack of local or government support may be one of the ups and downs of this operation.

\section{The Study Limitation}

In the West and Sub-Saharan region of Africa, various active terrorists and militant groups of different natures work together with violent political and criminal organizations and armed militia groups. These militant groups are dispersed all over Africa; nonetheless, they congruously work together with each other in various capacities to advance their respective interests. For the reason mentioned above, many studies must be conducted to understand further and address all of the militant groups' concerns, grievances, and demands. The scope of this research is limited to the understanding of economic damage and instability caused by the "Movement for the Emancipation of the Niger Delta (MEND)." 
This treatise calls for further studies to look into various perspectives on how the government should work with the community to counterterrorism and militant groups in the southern states in the Niger Delta region. As for future inquiries, they can conduct various studies in answering the following questions:

How might members of the community show that they are open to engaging constructively with the government?

What information could members of the southern Nigerian states be encouraged to share with the intelligence community?

How can community policing in southern states of Nigeria apply, as a thinking and organizational strategy, to countering terrorism and militant groups?

\section{Conclusions}

This research acknowledges the progress made by the Nigerian government since President Muhammadu Buhari came to power in March 2015. The Nigerian government has allocated millions of dollars and mobilized tens of thousands of soldiers to counter the Boko Haram insurgency with support from other neighboring African nations. Subsequently, Boko Haram and MEND have been pushed to the forest, and their forces to an extent have been diminished. However, many coordinated efforts are much needed because the militant groups remain active in the northern and southern regions of Nigeria and neighboring countries.

In this context, it is indispensable to incorporate the topic of violence into the study of community engagement and wellbeing from the perspective of working together with stakeholders and interdisciplinary perspectives from the fields of public security. Nigerian intelligence agencies cooperatively promote partnership to extend the possibilities of developing strategies, to respond in an expeditious way to the needs of people living in a community where MEND has a stronghold. Doing so will help the community overcome harm orchestrated by the militant groups operating in the Niger Delta.

The Nigerian government has a primary responsibility to provide economic incentives to compensate the community's financial loss through all its intelligence and police agencies. Also, the government must provide physical protection to the southern states against terrorism and uphold and protect human rights.

Nigeria is a global supplier of oil supplier not only to the U.S. but also to other African countries. The country has a significant influence in Africa, considering that it's the largest economy on the continent. Insurgency in Niger Delta is a menace to Nigeria's national security and the U.S. national security. Such acts threaten not only Nigeria's stability but also the stability of West Africa and the U.S. interest [56]. The region's insecurity is attributed to various issues such as corruption, political repression, land dispossession, marginalization, and pollution. Failure to address the security concerns in the area may worsen not only the country's economy but also other economies [57]. The stability of Nigeria is 
critical in boosting the U.S. prosperity and security, considering its regional influence and economic interests. In other words, "the Movement for the Emancipation of the Niger Delta (MEND)" poses threats to U.S. national security. Therefore, the U.S. must support the country to curb insurgency in the region.

\section{Conflicts of Interest}

The author declares no conflicts of interest regarding the publication of this paper.

\section{References}

[1] Redman, S.J. (2013) Historical Research in Archives. American Historical Association, Washington DC.

[2] British Broadcasting Corporation (BBC) (2009) The Curse of Nigerian Oil. http://news.bbc.co.uk/1/hi/programmes/from_our_own_correspondent/7808670.stm

[3] Courson, E. (2009) Movement for the Emancipation of the Niger Delta (MEND): Political Marginalization, Repression and Petro-Insurgency in the Niger Delta. Nordiska Afrika Institutet, Uppsala. https://www.files.ethz.ch/isn/112097/47.pdf

[4] Adisa, O.O. (2018) Implications of Using the Military and Para-Military Forces for Securitizing Nigerian Insecurities: The Case of Niger Delta Crisis. American International Journal of Social Science, 7, 46-57. https://doi.org/10.30845/aijss.v7n3p6

[5] Jones, V.C. (2009) U.S. Trade and Investment Relations with SSA and the African Growth and Opportunity Act. CRS Report No. RL31772, Congressional Research Service, Washington DC, 8. http://fpc.state.gov/documents/organization/128835.pdf

[6] Rosenau, W.G. (2009) Corporations and Counterinsurgency. RAND Corporation, Santa Monica.

[7] International Crisis Group (2015) Curbing Violence in Nigeria (III): Revisiting the Niger Delta. International Crisis Group, Brussels.

[8] Minority Rights Group (2019) Delta Minorities. https://minorityrights.org/minorities/delta-minority-groups/

[9] Nwagboso, C.I. (2018) Nigeria and the Challenges of Internal Security in the 21St Century. European Journal of Interdisciplinary Studies, 4, 15-33. https://doi.org/10.26417/ejis.v4i2.p15-33

[10] Amaraegbu, D. (2011) Violence, Terrorism and Security Threat in Nigeria's Niger Delta: An Old Problem Taking a New Dimension. African Journals of Political Science \& International Relations, 5, 208-217.

[11] Crenshaw, M. (1981) The Causes of Terrorism. Comparative Politics, 13, 379-399. https://doi.org/10.2307/421717

[12] Cable News Network (CNN) (2008) World's Most Valuable Resource, a Curse for Most Nigerians. https://www.cnn.com/2008/WORLD/africa/12/11/pip.nigeria.oil/index.html

[13] Mark, B.S. and Can, E.M. (2013) Research Methods in Critical Security Studies: An Introduction. Routledge, Abingdon, UK.

[14] Congressional Research Service (2007) DHS’s Risk Assessment Methodology: Evolution, Issues, and Options for Congress. http://www.fas.org/sgp/crs/homesec/RL33858.pdf

[15] Duerksen, M. (2021) Nigeria's Diverse Security Threats. https://africacenter.org/spotlight/nigeria-diverse-security-threats/ 
[16] Bier, V.M. (2007) Choosing What to Protect. Risk Analysis, 27, 607-620. https://doi.org/10.1111/j.1539-6924.2007.00906.x

[17] Alderson, D.L. (2013) Risk and Critical Infrastructure Systems: Practice and Pitfalls. Naval Postgraduate School, Monterey.

[18] Olajumoke, A. (2021) Confronting Nigeria's Kaduna Crisis. Africa Center for Strategic Studies, Washington DC.

https://africacenter.org/spotlight/confronting-nigerias-kaduna-crisis

[19] Nwalozie, C.J. (2020) Exploring Contemporary Sea Piracy in Nigeria, the Niger Delta, and the Gulf of Guinea. Journal of Transportation Security, 13, 159-178. https://doi.org/10.1007/s12198-020-00218-y

[20] Lia, B. and Skjølberg, K. (2004) Causes of Terrorism: An Expanded and Updated Review of the Literature? FFI/RAPPORT-2004/04307, Norwegian Defense Research Establishment, Kjeller.

[21] Keen, D. (1998) The Economic Functions of Violence in Civil Wars. Adelphi Paper No. 320, Oxford University Press/International Institute of Strategic Studies, Oxford.

[22] Sanderson, T.M. (2004) Transnational Terror and Organized Crime: Blurring the Lines. SAIS Review of International Affairs, 24, 49-61. https://doi.org/10.1353/sais.2004.0020

[23] Li, Q. and Schaub, D. (2004) Economic Globalization and Transnational Terrorism: A Pooled Time-Series Analysis. Journal of Conflict Resolution, 48, 230-258. https://doi.org/10.1177\%2F0022002703262869

[24] Jenkins, B. (1983) New Modes of Conflict. RAND Corporation, Santa Monica, 24 p.

[25] Zalik, A. (2004) The Niger Delta: 'Petro Violence' and 'Partnership Development. Review of African Political Economy, 31, 401-424. https://doi.org/10.1080/03056240420005512

[26] World Bank (2020) Nigeria on the Move: A Journey to Inclusive Growth. World Bank, Washington DC. https://openknowledge.worldbank.org/handle/10986/33347

[27] Mustapha, A.A. (2014) United States-Nigeria Relations: Impact on Nigeria's Security. Naval Postgraduate, Monterey.

[28] Ike, O. and Oronto, D. (2001) Where Vultures Feast: Shell, Human Rights, and Oil in the Niger Delta. Sierra Club Books, San Francisco, 45, 29.

[29] Amaraegbu, D (2010) Analysis of Anti-Corruption Policies in Africa: The Cases of Nigeria and Ghana. VDM Publishing House, Berlin.

[30] British Broadcasting Corporation (BBC) (2010) Nigeria Independence Marred by Blasts. http://www.bbc.co.uk/news/world-africa-11453668

[31] Duffield, C. (2010) Who Are Nigeria's Mend Oil Militants? BBC News, Lagos. http://www.bbc.co.uk/news/world-africa11467394

[32] Mouawad, J. (2007) Growing Unrest Posing a Threat to Nigerian Oil. New York Times.

[33] Bayart, J.-F. (1993) The State in Africa: The Politics of the Belly. Longman Group, England.

[34] Davis, S. (2009) The Potential for Peace and Reconciliation in the Niger Delta. Institute for Creation Research, Coventry.

[35] Ventura, L. (2005) Building a Security Policy Framework for a Large, Multinational Company. SANS Institute, Rockville.

[36] Rotberg, R. (2004) When States Fail: Causes and Consequences. Princeton University Press, Princeton. https://doi.org/10.1515/9781400835799

[37] Rice, S. (2003) The New National Security: Focus on Failed States. The Brookings 
Institution, Washington DC, 1-9.

[38] Ottaway, M. and Mair, S. (2004) States at Risk and Failed States. German Institute for International and Security Affairs, Berlin, 1-10.

[39] Krepinevich, A. (2010) 7 Deadly Scenarios: A Military Futurist Explores the Changing Face of War in the 21st Century. Bantam, London.

[40] Roland, P. (2004) At War's End: Building Peace after Civil Conflict. Cambridge University Press, Cambridge.

[41] Vinci, A. (2016) Beyond Terror and Insurgency: The LRA's Dirty War in Northern Uganda. In: Kassimeris, G., Ed., Warrior's Dishonour, Routledge, London, 81-98. https://doi.org/10.4324/9781315547640-5

[42] Adam, D. and Herman, B. (2016) Understanding the Lord's Resistance Army Insurgency. Vol. 11, World Scientific, Hackensack.

[43] Grobbelaar, A. and Solomon, H. (2015) The Origins, Ideology, and Development of Al-Qaeda in the Islamic Maghreb. Africa Review, 7, 149-161. https://doi.org/10.1080/09744053.2015.1030870

[44] Uzodike, U.O. and Maiangwa, B. (2012) Boko Haram Terrorism in Nigeria: Causal Factors and Central Problematic. African Renaissance, 9, 91-118.

[45] Udounwa, S.E. (2013) Boko Haram: Developing New Strategies to Combat Terrorism in Nigeria. U.S. Army War College, Carlisle Barracks. https://apps.dtic.mill

[46] Nye, J.S. (2004) Soft Power: The Means to Success in World Politics. Public Affairs, New York.

[47] Abu-Nimer, M. (2001) A Framework for Nonviolence and Peace Building in Islam. Journal of Law and Religion, 15, 217-265. https://doi.org/10.2307/1051519

[48] Dargiel, J. (2009) Smart Power: A Change in U.S. Diplomacy Strategy. E-International Relations.

[49] Richard, L.S. (2007) Conflict without Casualties: Non-Lethal Weapons in Irregular Warfare. Thesis, Naval Postgraduate School, Monterey CA, 6-7. http://www.bahaistudies.net/asma/nonlethal2.pdf

[50] Allison, G.T. and Kelley, P.X. (2004) Nonlethal Weapons and Capabilities. Council on Foreign Relations, Washington DC, 13-18.

[51] Stolberg, A. (2012) How Nation-States Craft National Security Strategy Documents. Strategic Studies Institute, Carlisle Barracks.

[52] Dagne, T. (2006) CRS Report for Congress: Nigeria in Political Transition. Congressional Research Service: The Library of Congress. http://fpc.state.gov/documents/organization/71824.pdf

[53] Cerami, J.R. (2001) U.S. Army War College Guide To Strategy. U.S. Army War College, Carlisle Barracks.

[54] Brown, C. (2007) The New Terrorism Debate Alternatives. Turkish Journal of International Relations, 3-4, 28-43. https://ciaotest.cc.columbia.edu/olj/tjir/v6n3_4/v6n3_4_brown.pdf

[55] Carter, P. (2007) Remarks on U.S. and International Cooperation in the Niger River Delta. https://2001-2009.state.gov/p/af/rls/rm/82010.htm

[56] Hazen, J.M, and Jonas, H. (2007) Small Arms, Armed Violence, and Insecurity in Nigeria. Small Arms Survey, Graduate Institute of International Studies, Geneva.

[57] Page, M. (2018) A New Taxonomy for Corruption in Nigeria, Carnegie Endowment for International Peace.

https://carnegieendowment.org/2018/07/17/new-taxonomy-for-corruption-in-niger ia-pub-76811 